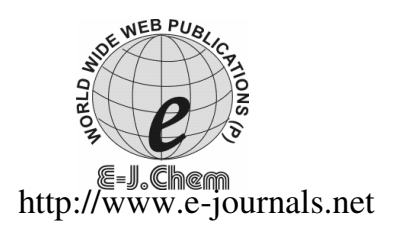

ISSN: 0973-4945; CODEN ECJHAO

E-Journal of Chemistry

2010, 7(4), 1426-1434

\title{
A Facile Spectrophotometric Method for the Determination of Cobalt(II) Using Iodine Monochloride Reagent
}

\author{
B. K. JAYANNA*, G. NAGENDRAPPA and NINGE GOWDA \\ *Department of Chemistry, B.N.M.Institute of Technology, \\ B.S.K. $2^{\text {nd }}$ Stage, Bangalore-560 070, Karnataka, India. \\ Department of Post Graduate Studies and Research in Chemistry, \\ Mysore University, Manasagngothri, 570 008, Karnataka, India. \\ anu_bidarur@yahoo.co.in
}

Received 7 January 2010; Accepted 3 March 2010

\begin{abstract}
A novel, simple, sensitive spectrophotometric method is proposed for the determination of cobalt(II). Chloromine-T with iodine in acetic acid produces iodine monochloride, which oxidizes promethazine hydrochloride and diphenylamine to absorbing cations. Those would associate later with cobalt complex to form an ion pair, $\left[\mathrm{Ph}^{+}\right]\left[\mathrm{CoCl}_{4}\right]^{-}$and $\left[\mathrm{Dh}^{2+}\right]\left[\mathrm{CoCl}_{4}\right]_{2}^{-}$in acid medium. These appear to provide exceptional color stability to the systems. The results compare favorably with those of reported method. The conditions required for the determination of cobalt(II) are described and related analytical parameters are also calculated.
\end{abstract}

Keywords: Spectrophotometry, Chloromine-T, Iodine monochloride, Ion-pairs.

\section{Introduction}

Cobalt is a naturally occurring element that appears in the first transition series of Group 9 (VIII) of the periodic table along with iron and nickel ${ }^{1}$. Cobalt commonly occurs in the $0,+2$ and +3 valence states ${ }^{2}$. Cobalt(II) is much more stable than $\mathrm{Co}(\mathrm{III})^{2}$. A biochemically important cobalt compound is vitamin $\mathrm{B}_{12}$. Vitamin $\mathrm{B}_{12}$ is a cofactor in critical biochemical reactions and is required for good health ${ }^{3}$. The largest use of metallic cobalt is in super alloys $^{4}$ that are used in gas turbines and aircraft engines.

The most commonly used techniques for the determination of cobalt(II) are emission spectrometric methods ${ }^{5,6}$, atomic absorption spectrophotometry (AAS) ${ }^{7}$, electrothermal atomic absorption spectrometry (ETAAS) ${ }^{8}$, Neutron activation analysis (NAA) ${ }^{9}$ and x-ray fluorescence method ${ }^{10}$. The AAS and ETAAS methods are very sensitive but need sophisticated 
instrumentation and expert hands. A few purely instrument based methods those use neutron activation analysis, $\mathrm{x}$-ray fluorescence etc., are not common for routine purposes. A wide variety of techniques are available for spectrophotometric determination of cobalt. Solvent extraction spectrophotometry ${ }^{11,12}$, spectrophotometric measurement after preconcentration with solid polymeric adsorbents such as amberliteXADs ${ }^{13}$ and polyurathanefoams ${ }^{14}$, spectrophotometric procedures using low melting point extrant ${ }^{15}$, simple spectrophotometry in aqueous solution ${ }^{16}$, derivative spectrophotometry ${ }^{17}$ and hydrogen point standard addition method in micellinzing solution have also been proposed ${ }^{18}$. Quinoline-8-ol ${ }^{19}$, dithizone ${ }^{20}$, zincon $^{21}$, 4-(2-pyridylazo) resorcinol(PAR $)^{22}$, chrome AzurolS ${ }^{23}$, are used as reagent for the determination of cobalt. Determination of cobalt using Quinoline-8-o ${ }^{19}$ and dithizone ${ }^{20}$ have low sensitivity and selectivity. Zincon ${ }^{21}$ is comparatively sensitive but the method is lacking selectivity, stability and reproducibility. 4-(2-pyridylazo) resorcinol (PAR) ${ }^{22}$, chrome azurol ${ }^{23}$ are relatively complicated and therefore organic solvent extractions are necessary using toxic solvent such as chloroform. Silverstone and $\mathrm{Bach}^{24}$ have described a spectrophtometric method for the determination of cobalt in nickel alloys by use of ethylenediaminetetraacetic acid and hydrogen peroxide at elevated temperature. Zora M. Grahovac also described the kinetic spectrophotometric ${ }^{25}$ method for the determination of cobalt ion by the oxidation of Ponceau $4 \mathrm{R}$ by hydrogen peroxide. Resacetophenoneoxime $^{26}$, bis(2,4,4-trimethylpentyl)monothio phosphinicacid (cyanex) ${ }^{27}$, chromeazophenol KS(CAKS $)^{28}$, 1-phenyl-1,2-butanedione dioxime $\left(\mathrm{H}_{2} \mathrm{PBDD}\right)^{29}$, 2-pyridyl-3'sulphophenylmethanone2-(5-nitro)pyridylhyrazone ${ }^{30}, 2$ ',4'-dihydroxy-5'-bromochalcone oxime ${ }^{31}$, 2-hydroxy-3-ethoxybenzaldehydethiosemicarbazone ${ }^{32}$ are used as reagent for the determination of cobalt at fixed $\mathrm{pH}$.

With this back ground of literature ${ }^{5-32}$ a new spectrophotometric method is described. The proposed method is simple, accurate and selective. Various techniques ${ }^{5-10}$ suffers because they are time consuming. Extraction procedure is always not quantitative ${ }^{11-15}$, critical $\mathrm{pH}$ maintenance $\mathrm{c}^{25-32}$ and heating ${ }^{24}$. The procedure neither requires any extraction, nor $\mathrm{pH}$ maintenance, nor coprecipitation, nor heating, nor any arrangement of sophisticated equipment. A spectrophotometer can be used for routine determination.

\section{Experimental}

UV-visible spectrophotometer with $10 \mathrm{~mm}$ matched quartz cells were used for absorbance measurements.

\section{Reagents}

\section{Chloromine-T-iodine reagent}

Iodine monochloride solution was prepared by dissolving $0.6164 \mathrm{~g}$ of chloromine-T (Loba chemie, Bombay, India) in $5 \mathrm{~mL}$ of acetic acid in a dry beaker and $0.2143 \mathrm{~g}$ of iodine (S.D.fine chemicals Pvt. Ltd., Bombay India) separately in $5 \mathrm{~mL}$ of acetic acid. Both these solutions were transferred into a $50 \mathrm{~mL}$ volumetric flask and diluted to the mark with acetic acid. The solution was found to be $0.043 \mathrm{M}$ (calculated) with respect to iodine monochloride.

Promethazine hydrochloride reagent $\left(0.0015 \mathrm{~mol} \mathrm{~L}^{-1}\right)$

Prepared by dissolving $0.0342 \mathrm{~g}$ of promethazine hydrochloride(Rhone Poulene Laboratories(India) in $100 \mathrm{~mL}$ of distilled water.

Sodium diphenylamine $\left(0.0073 \mathrm{~mol} \mathrm{~L}^{-1}\right)$

Prepared by dissolving $0.2 \mathrm{~g}$ of Sodium diphenylamine (S.D.fine chemicals Pvt. Ltd., Bombay India) in $100 \mathrm{~mL}$ distilled water. All other chemicals, reagents and solvents used were of analytical grade. 


\section{General procedure}

Aliquots of the standard Co(II) solutions containing 10 to55 $\mu \mathrm{g} / \mathrm{mL}$ were transferred to a series of $10 \mathrm{~mL}$ volumetric flasks. To each one of these flasks $0.75 \mathrm{~mL}$ iodine monochloride $(0.009 \mathrm{M})$ followed by $1.5 \mathrm{~mL}$ of promethazine hydrochloride were added. The volume was made up to $10 \mathrm{~mL}$ with water and mixed thoroughly. Absorbance of these solution were measured at $520 \mathrm{~nm}$ after 30 minutes making zero absorbance with distilled water.

Similarly for the reagent sodium diphenylamine, aliquots of the standard $\mathrm{Co}$ (II) solutions containing 5 to $75 \mu \mathrm{g} / \mathrm{mL}$ were transferred into a series of $10 \mathrm{~mL}$ volumetric flasks. To each one of these flasks $0.5 \mathrm{~mL}$ of iodine monochloride $(0.043 \mathrm{M}), 1 \mathrm{~mL}$ of sodium diphenylamine and $1.5 \mathrm{~mL}$ of $1.25 \mathrm{M}$ sulfuric acid were added. The volume was made up to $10 \mathrm{~mL}$ with water and mixed thoroughly. Absorbance of these solution were measured at $530 \mathrm{~nm}$ making zero absorbance with distilled water.

\section{Results and Discussion}

The method proposed here for the determination of $\mathrm{Co}(\mathrm{II})$ is based on the oxidation promethazine hydrochloride, sodium diphenylamine with iodine monochloride. Chloromine-T with iodine in acetic acid produces iodine monochloride. Iodine monochloride first oxidizes $\mathrm{Co}(\mathrm{II})$ to $\mathrm{Co}(\mathrm{III})$. Unreacted iodine monochloride oxidizes promethazine hydrochloride to absorbing cations ${ }^{33}\left(\left[\mathrm{Ph}^{+}\right]\right)$. The radical cation would associated with $\left[\mathrm{CoCl}_{4}\right]^{-}$to form ion-pairs $\left[\mathrm{Ph}^{+}\right]\left[\mathrm{CoCl}_{4}\right]^{-34-35}$ which are appeared to be providing colour stability to the system. Ion-pair prevents the promethazine hydrochloride to further oxidation to colourless sulfoxides ${ }^{36}$. In case of diphenylamine, diphenylamine is first oxidized into colorless diphenylbenzidine $^{37}$ and is reversible further oxidized to diphenylbenzidine violet. Diphenylbenzidine violet undergoes further oxidation in presence of excess of iodine monochloride solution to diphenylbenzidinium cations ${ }^{38}\left(\left[\mathrm{Dh}^{2+}\right]\right)$. The radical cation diphenylbenzidinium would associated with $\left[\mathrm{CoCl}_{4}\right]^{-}$to form ion-pairs $\left[\mathrm{Dh}^{2+}\right]\left[\mathrm{CoCl}_{4}\right]_{2}^{-}$. Application of the method for determination of Cobalt(II)

Various synthetic mixtures containing Cobalt were prepared and each was analyzed according to recommended procedure and the results were tested by known method. Results obtained are summarized in Table 1. They show a good agreement between the amounts added and estimated.

Table 1. Determination of Cobaltl(II) in Synthetic mixture

\begin{tabular}{|c|c|c|c|c|}
\hline \multirow{2}{*}{ Mixtures ${ }^{* *}$} & \multirow{2}{*}{$\begin{array}{l}\text { Amount } \\
\text { added } \\
/ \mu \mathrm{g}\end{array}$} & \multicolumn{2}{|c|}{ Amount found ${ }^{*} / \mu \mathrm{g}$} & \multirow[b]{2}{*}{$\begin{array}{l}\text { Reference } \\
\text { Method }^{39,40}\end{array}$} \\
\hline & & $\begin{array}{c}\text { Promethazine } \\
\text { Hydrochloride method }\end{array}$ & $\begin{array}{c}\text { Sodium } \\
\text { diphenylamine method }\end{array}$ & \\
\hline $\begin{array}{l}\mathrm{Co}(\mathrm{II})(20) \\
\mathrm{Pb}(1000)\end{array}$ & 10 & $9.89(1.1 \%)$ & $9.85(1.5 \%)$ & $9.96(0.37 \%)$ \\
\hline $\begin{array}{l}\mathrm{Co}(20) \\
\operatorname{Mn}(50) \\
\mathrm{Fe}(50)\end{array}$ & 20 & $19.9(0.005)$ & $19.98(0.001)$ & $19.9(0.005)$ \\
\hline $\begin{array}{l}\mathrm{Co}(20) \\
\mathrm{Ce}(50) \\
\operatorname{Pb}(50)\end{array}$ & 20 & $19.95(0.0025)$ & $19.9(0.005)$ & $19.8(0.01)$ \\
\hline $\begin{array}{c}\mathrm{Co}(20) \\
\mathrm{Cd}(50) \\
\mathrm{V}(50)\end{array}$ & 20 & $19.8(0.01)$ & $19.9(0.005)$ & $19.8(0.01)$ \\
\hline
\end{tabular}

* An average of three determinations, ** Values are in $\mu \mathrm{g}, \cdot \mathrm{Fe}$ was masked by sodium fluoride 


\section{Optimization}

The effect of reagent concentrations

Various amount of $0.043 \mathrm{M}$ iodine monochloride solution was added to a solution containing $30 \mu \mathrm{g}$ of $\mathrm{Co}(\mathrm{II})$. The maximum constant absorbances were obtained by adding $0.75 \mathrm{~mL}$ of iodine monochloride solution $(0.009 \mathrm{M})$ for promethazine hydrochloride and $0.5 \mathrm{~mL}$ of iodine monochloride $(0.043 \mathrm{M})$ solution for sodium diphenylamine.

\section{Effect of acids on the color stability}

Color stability and intensity of solutions were found to depend on the nature and concentration of acid used. The solutions with $2 \mathrm{M} \mathrm{H}_{2} \mathrm{SO}_{4}, 2 \mathrm{M} \mathrm{HCl}$ and $2 \mathrm{M} \mathrm{CH}_{3} \mathrm{COOH}$ were found to decrease the color with time and finally the solutions discharge their color completely in 10 minutes. But the solutions with $1.75 \mathrm{M} \mathrm{CH}_{3} \mathrm{COOH}$ for $\left[\mathrm{CoCl}_{4}\right]^{-}\left[\mathrm{Ph}^{+}\right]$was found to be having color stable for 15 minutes.

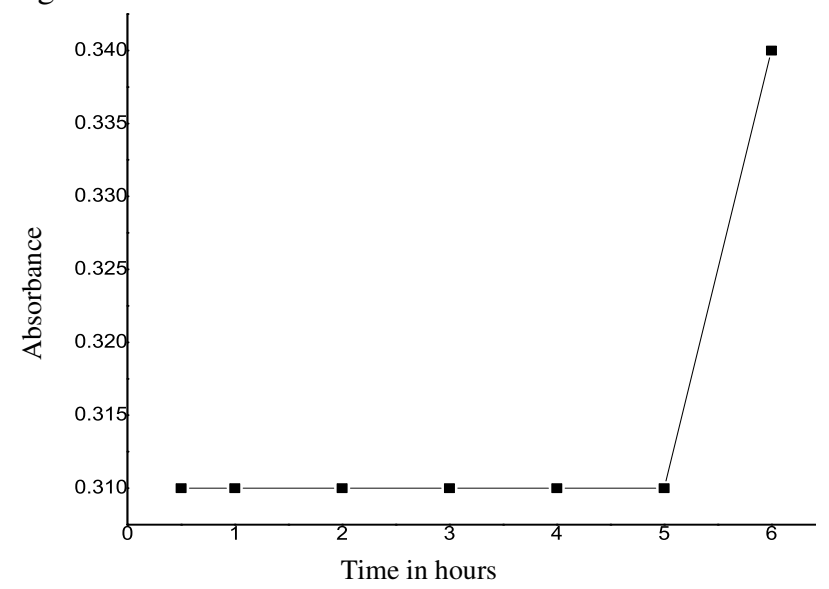

Figure 1. Effect of time on color stability of $\left[\mathrm{Dh}^{2+}\right]\left[\mathrm{CoCl}_{4}\right]_{2}{ }^{-}$complex

The absorbance of the colored solution was measured at various intervals of time (Table.2). The color intensity increases after 5 hours therefore it is recommended to measure the absorbance with in the first 5 hours.

Table 2. Stability of the color of the $\left[\mathrm{Dh}^{2+}\right]\left[\mathrm{CoCl}_{4}\right]_{2}{ }^{-}$complex

\begin{tabular}{cc}
\hline Time in hour & Absorbance at $530 \mathrm{~nm}$. \\
\hline 0.5 & 0.31 \\
1.0 & 0.31 \\
2.0 & 0.31 \\
3.0 & 0.31 \\
4.0 & 0.31 \\
5.0 & 0.31 \\
6.0 & 0.34 \\
\hline
\end{tabular}

\section{Effect of sulfuric acid}

The effect of varying the concentration of sulfuric acid on $\left[\mathrm{CoCl}_{4}\right]_{2}{ }^{-}\left[\mathrm{Dh}^{2+}\right]$ complex. The rate of color development and the sensitivity of the reaction increased with increasing sulfuric acid concentration up to $1.25 \mathrm{M}$. Full color development occurred over this concentration and is stable for more than 5 hours. 
Table 3. Effect of varying the concentration of sulfuric acid on $\left[\mathrm{Dh}^{2+}\right]\left[\mathrm{CoCl}_{4}\right]_{2}{ }^{-}$complex

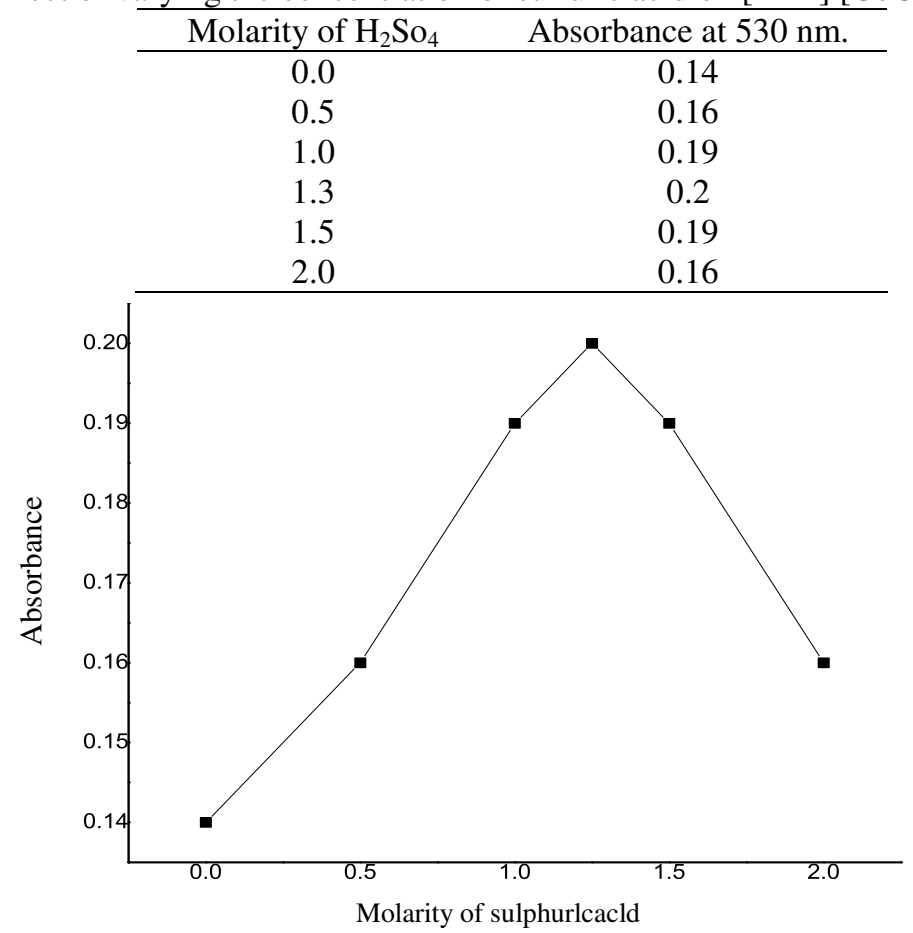

Figure 2. Effect of sulfuric acid on $\left[\mathrm{Dh}^{2+}\right]\left[\mathrm{CoCl}_{4}\right]_{2}{ }^{-}$complex

\section{Composition of the ion pair complex}

Job's method of continuous variation was employed for the determination of the composition of the ion-pair complexes. Both $\left[\mathrm{Dh}^{2+}\right]$ to $\left[\mathrm{CoCl}_{4}\right]_{2}{ }^{-}$and $\left[\mathrm{Ph}^{+}\right]$to $\left[\mathrm{CoCl}_{4}\right]^{-}$were found to be $1: 1$.

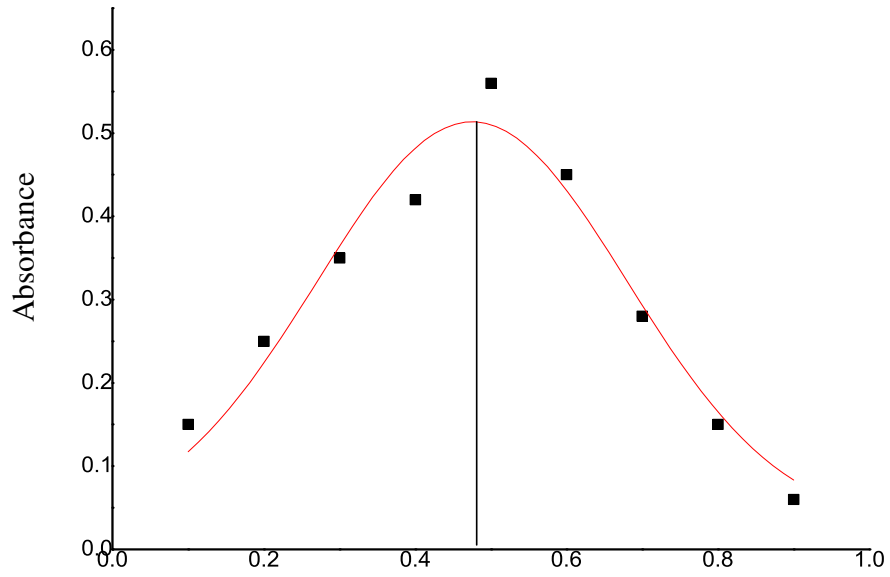

[Diphenylamine] / [Co(II) Iodine monochloride+ Diphenylamine]

Figure 3. Continuous variation method. [diphenylamine]: 0.01 M [Iodine monochloride]: $0.01 \mathrm{M}$ and $\mathrm{Co}(\mathrm{II})=0.01 \mathrm{M}$ 


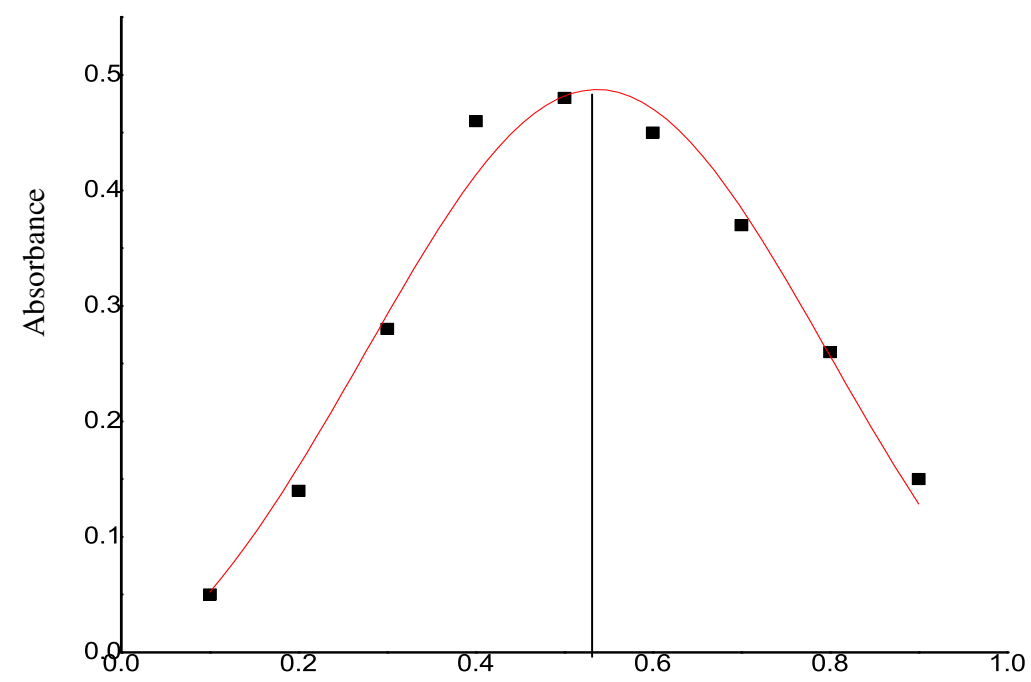

[promethazine hydrochloride] / [Co(II) Iodine monochloride + promethazine hydrochloride]

Figure 4. Continuous variation method, [promethazine hydrochloride]:0.001 M [Iodine monochloride]: $0.001 \mathrm{M}$ and $\mathrm{Co}(\mathrm{II})=0.001 \mathrm{M}$

\section{Absorption curve}

The absorption curve for ion-pair complexes was obtained by the recommended procedures. The absorption maxima of the colored solutions at $520 \mathrm{~nm}$ for $\left[\mathrm{Ph}^{+}\right]\left[\mathrm{CoCl}_{4}^{-}\right]$as shown in Figure 5 and for $\left[\mathrm{Dh}^{2+}\right]\left[\mathrm{CoCl}_{4}\right]_{2}{ }^{-}$at $530 \mathrm{~nm}$ in Figure 6.

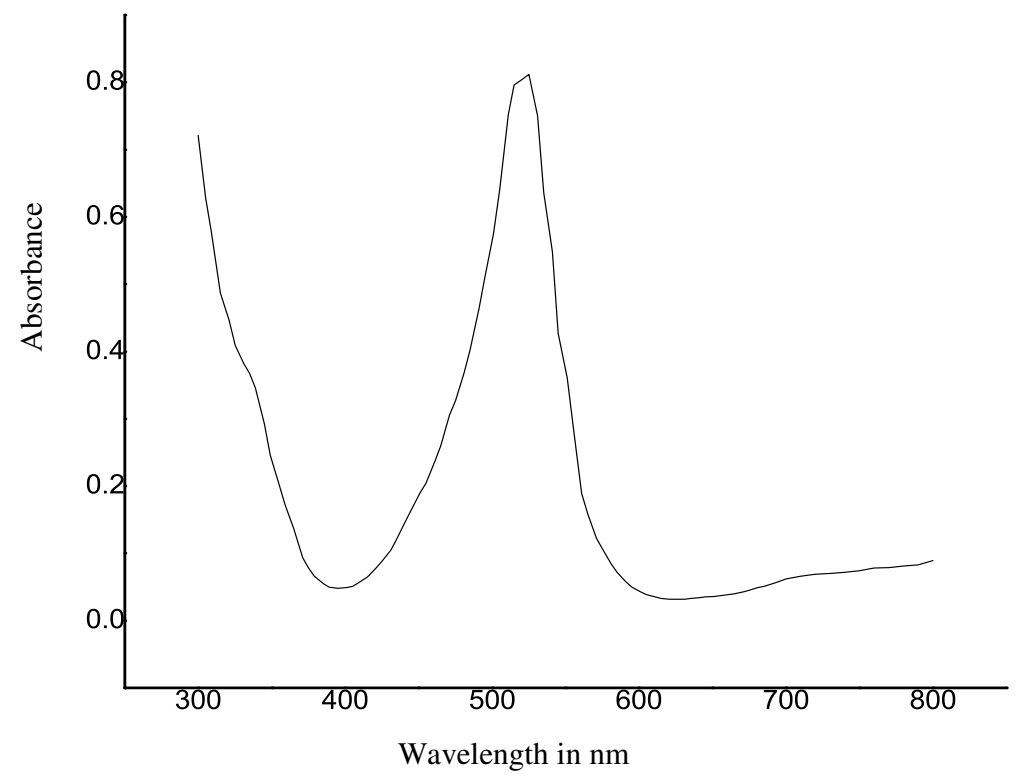

Figure 5. Absorption spectrum of $\left[\mathrm{Ph}^{+}\right]\left[\mathrm{CoCl}_{4}^{-}\right](\mathrm{Co}(\mathrm{II})(10 \mu \mathrm{g})+0.75 \mathrm{~mL}$ iodine monochloride $(0.009 \mathrm{M})+1.5 \mathrm{~mL}$ Promethazine hydrochloride + diluted to $10 \mathrm{~mL}$ with water) 


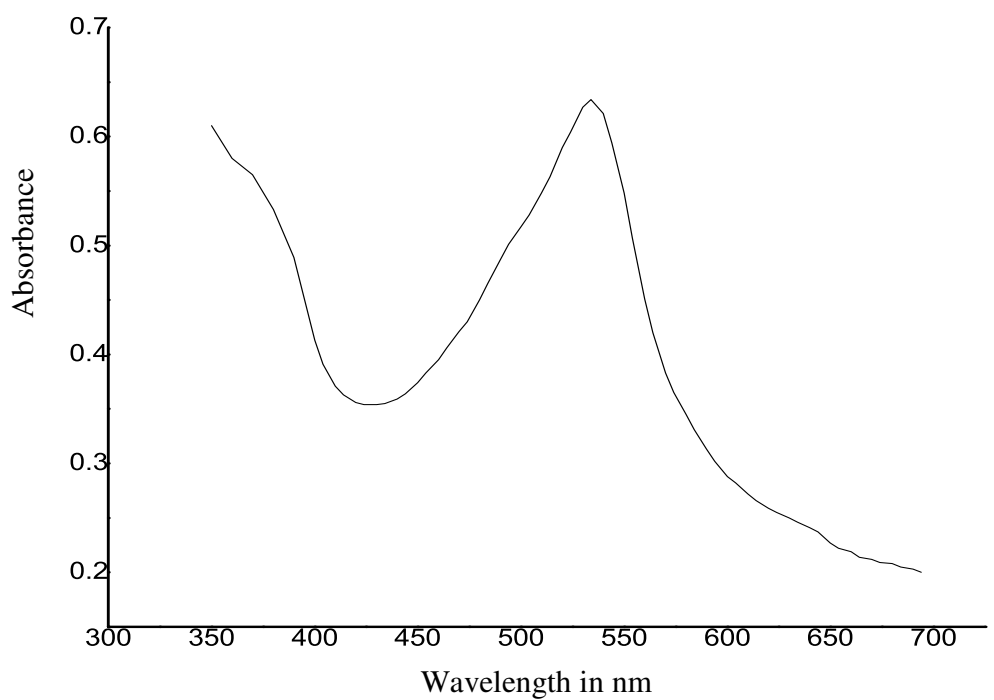

Figure 6. Absorption spectrum of $\left[\mathrm{Dh}^{2+}\right]\left[\mathrm{CoCl}_{4}\right]_{2}^{-}(\mathrm{Co}(\mathrm{II})(10 \mu \mathrm{g})+0.5 \mathrm{~mL}$ iodine monochloride $(0.043 \mathrm{M})+1 \mathrm{~mL}$ sodium diphenylamine $+1.5 \mathrm{~mL} \mathrm{H}_{2} \mathrm{SO}_{4}(1.25 \mathrm{M})+$ diluted to $10 \mathrm{~mL}$ with water)

\section{Calibration curves}

The calibration curve for Co(II) was prepared by recommended procedures as shown in Figure 7 and 8. Linear relationships between absorbance and concentration held over range of 10 to $55 \mu \mathrm{g} / \mathrm{mL}$ for promethazine hydrochloride and 5 to $75 \mu \mathrm{g} / \mathrm{mL}$ for sodium diphenylamine and other parameters are given in Table 4.



Figure 7. $\mathrm{Co}(\mathrm{II})+0.75 \mathrm{~mL}$ iodine monochloride $(0.009 \mathrm{M})+1.5 \mathrm{~mL}$ promethazine hydrochloride + diluted to $10 \mathrm{~mL}$ 


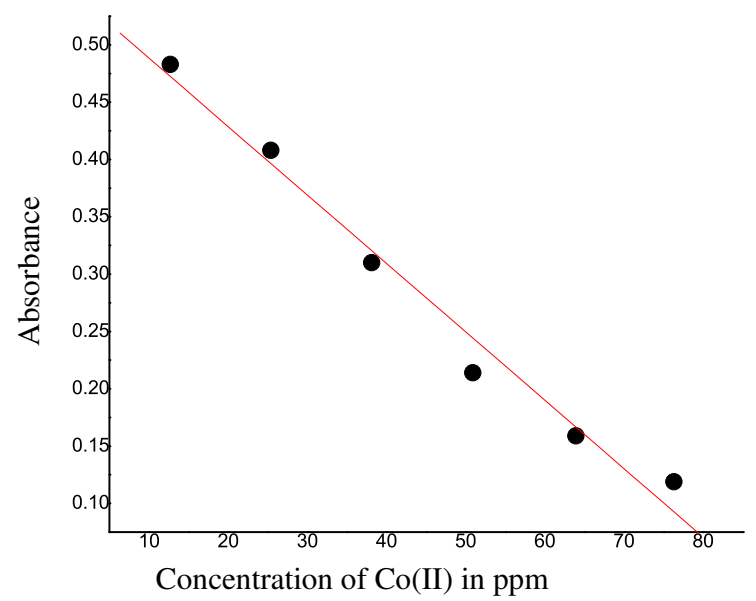

Figure 8. $\mathrm{Co}(\mathrm{II})+0.5 \mathrm{~mL}$ iodine monochloride $+1 \mathrm{~mL}$ sodium diphenylamine $+1.5 \mathrm{~mL}$ sulfuric acid $(1.25 \mathrm{M})+$ diluted to $10 \mathrm{~mL}$

Table 4. Optical characteristics of the proposed procedure

\begin{tabular}{lcc}
\hline \multicolumn{1}{c}{ Parameters } & Promethazine hydrochloride & Sodium diphenylamine \\
\hline$\lambda_{\max }, \mathrm{nm}$ & 520 & 530 \\
Beer's limit, $\mu \mathrm{g} / \mathrm{mL}$ & $10-55$ & $5-75$ \\
Molar absorptivity L mol ${ }^{-1} \mathrm{~cm}^{-1}$ & 1048.5589 & 692.47292 \\
Sandelsensitivity & 0.0562 & 0.0851125 \\
$\left(\mu \mathrm{g} \mathrm{cm}^{-2} / 0.001 \mathrm{~A}\right)$ & & -0.99013 \\
Correlation coefficient & -0.99641 & -0.00597 \\
Regression equation Slope(b) & -0.0019 & 0.54804 \\
Intercept(a) & 0.4749 & $0.5567(3.2)$ \\
Relative standard deviation, $\%$ & $0.17075(3.0)$ & $1: 1$ \\
Stoichiometry & $1: 1$ & \\
\hline
\end{tabular}

\section{Interferences}

For the interference studies, $10 \mathrm{mg}$ salt of the anion or $1 \mathrm{mg}$ of the cation were added individually to a solution containing $30 \mu \mathrm{g}$ of cobalt and determined by the general procedure. It was observed that, sulphate, acetate does not interfere. Among the cations studied, $\mathrm{Cd}(\mathrm{II}), \mathrm{Zn}(\mathrm{II}), \mathrm{Mn}(\mathrm{II})$, and $\mathrm{V}(\mathrm{V})$ did not interfere. $\mathrm{Fe}(\mathrm{II}), \mathrm{Ce}(\mathrm{IV})$ and $\mathrm{Pb}(\mathrm{II})$ interfered. $\mathrm{Fe}$ (II) and $\mathrm{Fe}(\mathrm{III})$ were masked with $2 \mathrm{~mL}$ of $5 \%$ sodium fluoride. $\mathrm{Pb}$ (II) was separated as $\mathrm{PbSo}_{4}$ and $\mathrm{Ce}(\mathrm{IV})$ was separated as $\mathrm{Ce}(\mathrm{IV})$ phosphate.

\section{Conclusion}

Once the iodine monochloride reagent is prepared, it is stable for more than a week ${ }^{41}$. For a good reproducibility of the results, it is desirable to use the same iodine monochloride for the preparation of standard and test solutions of the Co(II). Persistence of color of the sodium diphenylamine solutions for than $24 \mathrm{~h}$ also with promethazine hydrochloride. The proposed method is economical, sensitive and the results are reproducible with a good stability in the color of the sodium diphenylamine solution and a very little stability in the color of the promethazine hydrochloride solution under the optimized condition. The proposed method offers several advantages. The procedure does not require any extraction, $\mathrm{pH}$ maintenance, coprecipitation, heating, centrifuge, any elaborate equipment and the method is less expensive.

\section{Acknowledgments}

One of the authors Jayanna.B.K thanks the BNM Institute of Technology, Bangalore for the encouragement to publish the research paper. 


\section{References}

1. Morral F R, Cobalt and Cobalt alloys, in Standen A (Ed.): Kirk Othmer Encyclopedia of Chemical Technology, Ed 2 rev. New York, Interscience Publishers, 1970, 5, 716-748.

2. Cotton F A and Wilkinson G, Advanced inorganic chemistry, $4^{\text {th }}$ Ed. New York: John Wiley \& Sons, 1980.

3. Da Silva J J R F and Williams R J P, The Biological Chemistry of the Elements Clarendon Press Oxford, 1991.

4. Mineral Commodity Profiles- Cobalt. US Dept of Interior Bureau of Mines, 1997, 19.

5. Sugimae A, Anal Chem., 1975, 47, 1840- 43.

6. Seely J L and Skogerboe R K, Anal Chem., 1974, 46, 415-21.

7. Atomic absorption spectrophotometer facilitates water analysis Water Sewage Works, 1974, 1, 27, 45.

8. Akman S and Doner G, Spectrochim Acta Part B., 1995, 50, 975.

9. Dams R, Robbins J A, Rahn K A andWinchester J W, Anal Chem., 1970, 42, 861-67.

10. Dzubay T G and Stevens R K, Environ Sci Technol., 1975, 9, 663-68.

11. Barakat S A, Rusan M and Burns D T, Anal Chim Acta., 1997, 355,163.

12. Shima C, Nukatuka I and Ohzeki K, Anal Sci., 1998, 14, 337.

13. Sakai Y and Mori N, Talanta, 1986, 33,161.

14. Carvalho M S, Fraga I C S, Neto K C M and SilvaFilho E Q, Talanta, 1996,43,1675.

15. Taher M A, Anal Sci., 2000, 16, 501-506.

16. Themelis D.G, Zachariaidis G A and Stratis J A, Analyst, 1995, 120, 1593.

17. Eskandari H and Ghanbari Saghseloo A, Anal Sci., 2003, 19, 1513.

18. Eskandari H and Bagherian Dehaghi G H, Mikrochim Acta., 2004.

19. Balnco M, Coello J, Gonzalez F, Iturriaga H and Maspoch.S, Anal Chim Acta, 1900, 230, 221.

20. Dawson.M V and Lyle S J, Talanta, 1990, 37, 1189.

21. Morris A G, Analyst (London), 1957, 82, 34.

22. Sekheta M S, Milosonovic G A and Tanji T S, Mikrochim Acta, 1978, 8, 297.

23. Mauliya S G, Pyatnitskii I V and Kolements L K, Anal Chem (Warsaw), 1981, 35, 861.

24. Silverstone N M and Bach B B, Metallurgia, 1961, 63, 205.

25. Zora M Grahovac, Mitić Snežana S, Pecev Emilija T and Tošić Snežana B, J Serb Chem Soc., 2006, 71(2), 189-196.

26. Krishna Reddy V, Mutta Reddy S, Raveendra Reddy P and Sreenivasulu Reddy T, Indian J Chem., 2000, 39, 557.

27. Ajgaonkar H S and Dhadke P M, Indian J Chem., 1996, 3(6), 358.

28. Hong-wen Gao, Indian J Chem., 1998, 37A, 367.

29. Tejam A B and Thakkar N V, Indian J Chem., 1998, 5, 155.

30. Tsugikatsu odashima, Takemitsukikuchi, Wataruohtani and Hajime Ishii, Desai A M and desai K K, Asian J Chem., 2004, 16(2), 1228.

31. Paria P K, T K Thokdar and Majumdar S K, Indian J Chem., 1986, 25A, 103.

32. Kumar A P, Reddy P R and Reddy V K, J Ana Chem., 2008, 63(1), 26-29.

33. Dwived P C, Gurudath Rao S N, Bhat S N and Rao C N R, Spectrochimica Acta, 1975, 31A, 129-135.

34. Lee, Jung M, Hur M, Ahn M and Yakhak Hocchi, Anal Sci., 1998, 42, 243.

35. Bhongade S L and Kasture A V, Indian J Pharm Sci., 1993,55,154.

36. Forrest I S, Forrest F M and berger M, Biochim Biophys Acta, 1958, 29, 441.

37. Vogel A I, A Text Book of Quantitative Inorganic analysis $3^{\text {rd }}$ Edn, Longmans, India, p.443.

38. Wang L, Wang Q Q and Cammarata V, J Electrochem Soc., 1998, 145(8), 2648.

39. Tejam A B and Thakkar N V, Indian J Chem Techn., 1998, 5, 155.

40. More P S and Sawant A D, Indian J Chem., 1992, 31A, 984.

41. Nagendrappa G, Subramanya Raj Urs S and Rajalakshmi S, J Am Oil Chem Soc., 1999, 76(8), 1001. 


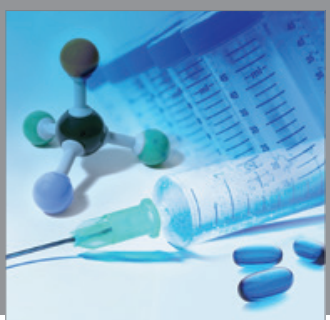

International Journal of

Medicinal Chemistry



Carbohydrate Chemistry

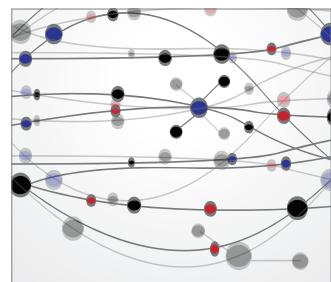

The Scientific World Journal
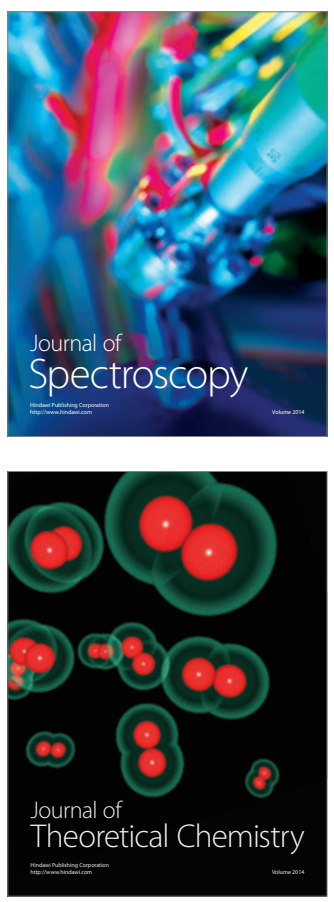
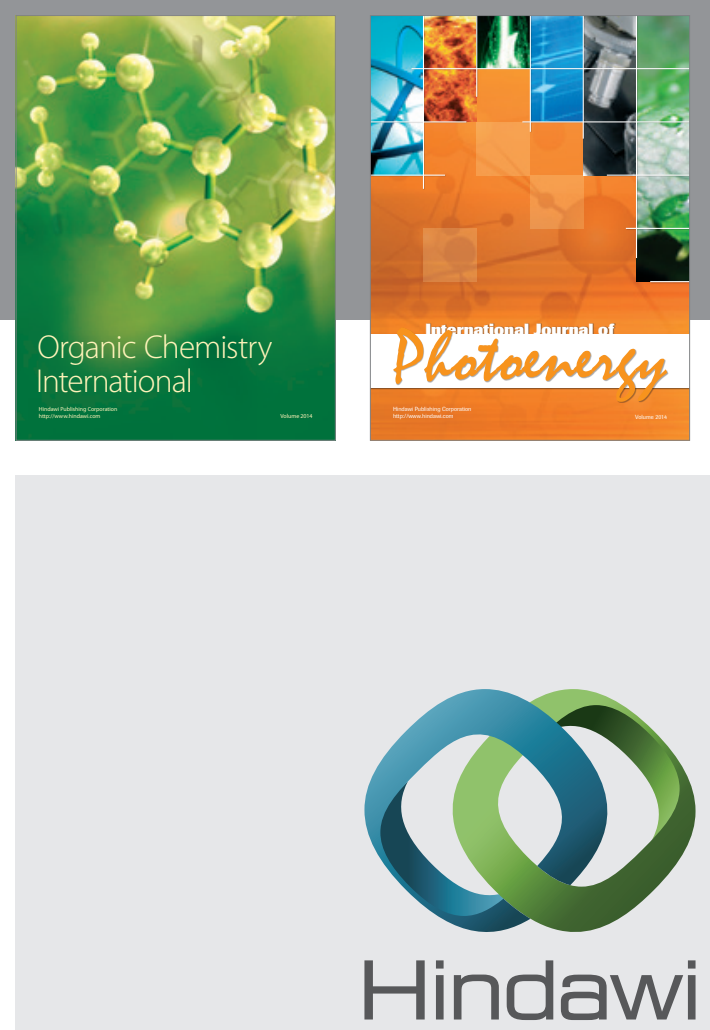

Submit your manuscripts at

http://www.hindawi.com
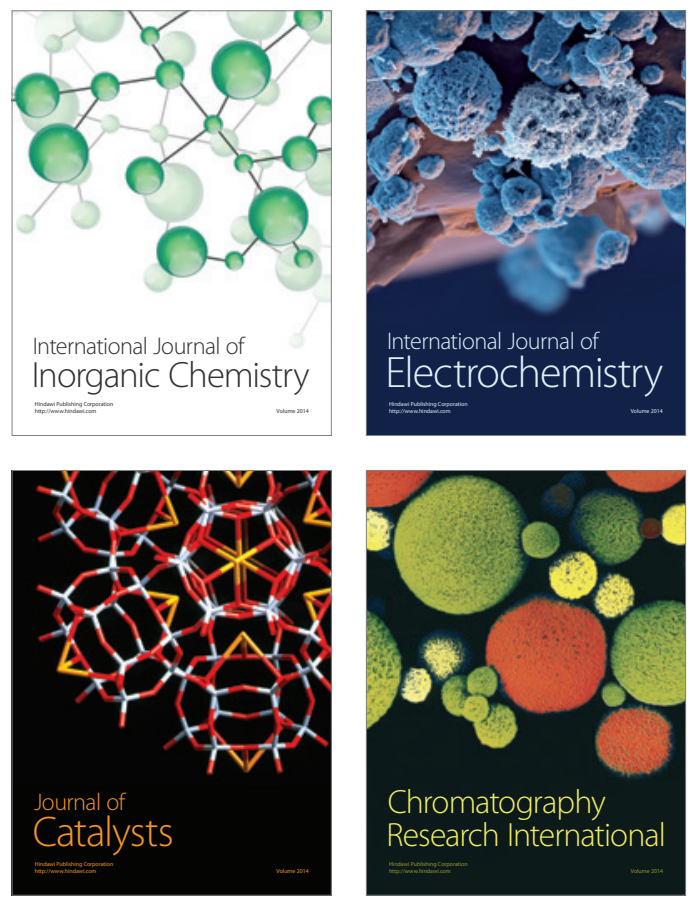
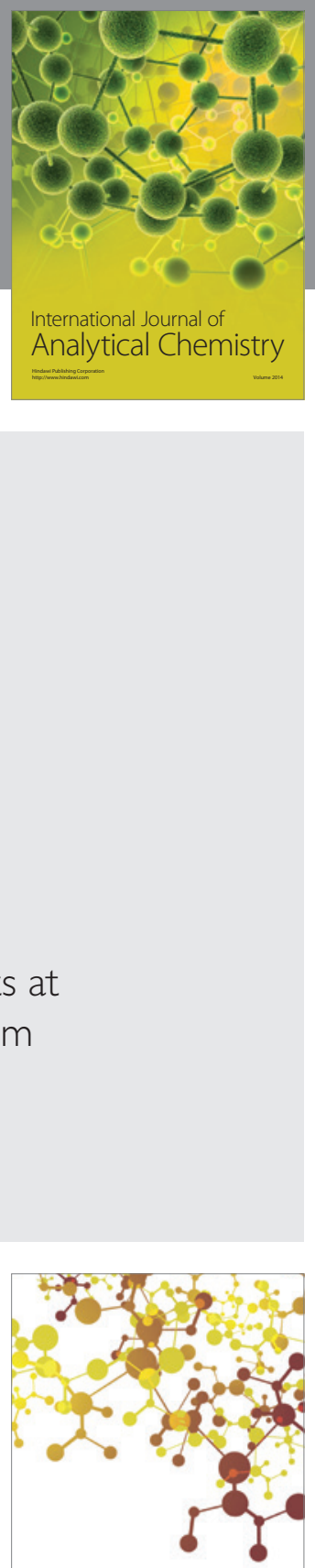

Journal of

Applied Chemistry
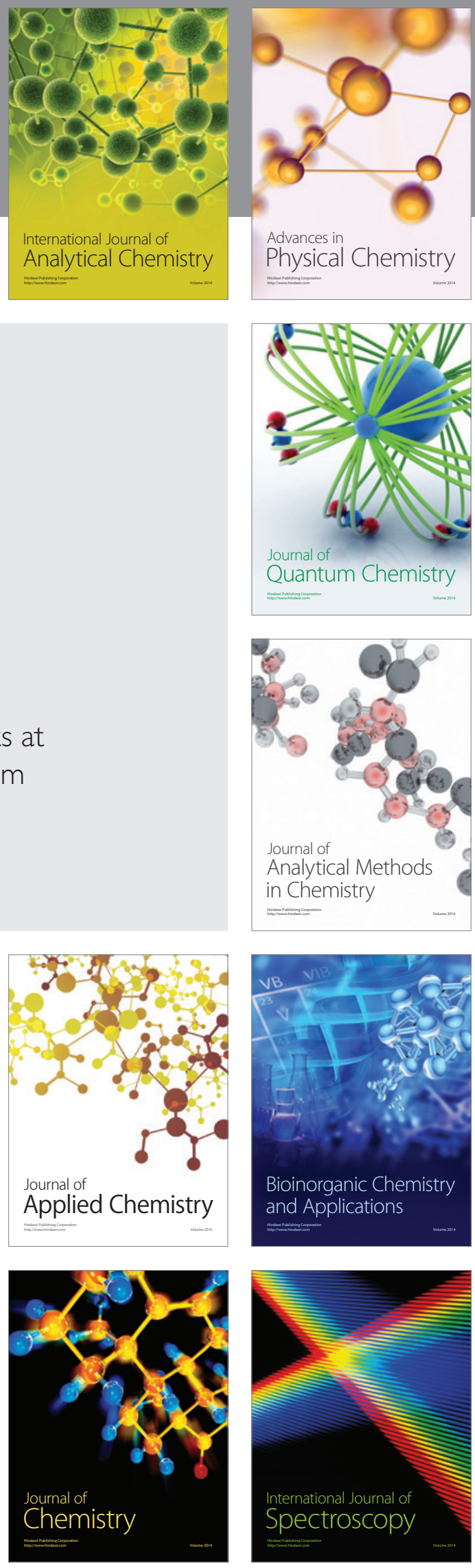